\title{
Enhancement of Gum Solubility by Single Process of Humidification and Drying (Granulation)
}

\section{Alkarib $\mathrm{SY}^{1^{*}}$ and Nour WF${ }^{2}$}

${ }^{1}$ College of Pharmacy, Karary University, Sudan

${ }^{2}$ National Medicine and Poisons Board, Sudan

*Corresponding author: Alkarib SY, College of Pharmacy, Karary University, Sudan, Tel: 00249 12304739; E-mail: ombasil1@yahoo.com

Received date: December 17, 2016; Accepted date: February 03, 2017; Published date: February 06, 2017

Copyright: (C) 2017 Alkarib SY, et al. This is an open-access article distributed under the terms of the Creative Commons Attribution License, which permits unrestricted use, distribution, and reproduction in any medium, provided the original author and source are credited.

\begin{abstract}
Gum arabic is a complex, loose aggregate of sugars and hemicelluloses composed of Arabic acid nucleus connected with calcium, magnesium, potassium and sugars Arabinose, Galactose, and Rhamnose. It is found in mechanically ground or spray dried forms. The solubility varies between $2 \mathrm{~h}$ in the raw gum form and 20 min in spray dried form. This study tended to enhance the solubility by producing an instant soluble granulated form.

The study was performed using atomized fluid bed drier. $50 \mathrm{~kg}$ of raw gum, subjected first to mechanical comminuting into powder, then treated with water by spraying at rate of $200 \mathrm{~mL} / \mathrm{min}$ for $90 \mathrm{~min}$. The inlet temperature was $70^{\circ} \mathrm{C}$, and the outlet temperature was $40^{\circ} \mathrm{C}$. The cabinet temperature was $40^{\circ} \mathrm{C}$. Finally after water treatment process, the powder resized through Mesh size of $40 \mu \mathrm{m}$ and the microbial test was done for the finished product.

The solubility of the granulated instant soluble gum in room temperature was found to be less than 5 min compared to the spray dried form which is $20-30 \mathrm{~min}$ and $2 \mathrm{~h}$ for mechanical ground gum. The volume increased to three times compare to the mechanical form.

It was concluded that granulation of gum under water spray significantly enhances the solubility and hence it is beneficial for uses in pharmaceutical technology.

This study tended to produce a form of granulated gum which is easily soluble compared to the mechanically ground and spray dried forms.
\end{abstract}

Keywords: Gum arabic; Granulation; Solubility; Pharmaceutical technology

\section{Introduction}

Gum acacia is dried exudate obtained from the stems and branches of Acacia senegal (Linne) Willdenow or other related species of Acacia (Family: Leguminosae) that grow mainly in the Sudan and Senegal regions of Africa [1]. The bark of the tree is incised and the exudate is allowed to dry on the bark. The dried exudate is then collected, processed to remove bark, sand, and other particulate matters and then graded according to particle size, purity and other physical properties [2]. Gum Arabic (Acacia senegal) is a branched-chain, complex polysaccharide, either neutral or slightly acidic so found as a complex mixture of calcium, magnesium and potassium salt of a polysaccharide acid or as a complex branched polysaccharide that contains Dgalactose, L-rhamnose, D-glucuromic acid and L-arabinose residues. These sugars constituents of gum Arabic are the same but composition and molecular weight of the gum varies from species to species in the range of 260,000-1,160,000 G [3].

The viscosity of Gum Arabic solution is affected by a number of factors which include age of parent tree, rainfall during the harvesting season, time of exudation and type of storage conditions. Thus viscosities of solutions of gum arabic of similar grades can vary by as much as more than $50 \%$ and are affected differently by concentration, temperature, $\mathrm{pH}$, salt content and presence of other electrolytes. Gum Arabic as found in nature exists as a natural or slightly acidic calcium, magnesium, potassium or sodium salt of complex polysaccharide and the different metal ions present in gum arabic molecules affect the Gum Arabic viscosity, where monovalent ions increase gum viscosity while divalent ions decrease it. However, research directed towards understanding the relationship between soil type containing these metal ions and rainfall to viscosity of Gum Arabic is lacking [4].

The gum is a complex, loose aggregate of sugars and hemicelluloses with a molecular weight of approximately $240000-580000$, which are composed of Arabic acid nucleus connected with calcium, magnesium, and potassium along with the sugars Arabinose, Galactose, and Rhamnose [5]. Gum acacia is available as odorless, bland taste; white or yellowish-white thin flakes, spheroidal tears, granules, powder, or spray-dried powder [6].

The gum is mainly used in oral and topical pharmaceutical formulations as a suspending and emulsifying agent [7]. It is also used in the preparation of pastilles and lozenges, and as a tablet binder. It has also been evaluated as a bioadhesive and has been used in novel tablet formulations, and modified release tablets [8]. Gum acacia is also used in cosmetics, confectionery, food products, and spray-dried flavors [9]. Gum Arabic or gum acacia is a natural gum is made from 
Page 2 of 4

African acacia tree. It is one of the world's most-common gums and can boast the longest history and has approved by FDA as pharmaceutical products that use in a wide variety of applications mainly as tablet binder, film forming agent, emulsifier, and suspending agent. Also it has been processing and supplying into the food, beverage, and pharmaceutical markets for many years and are a significant supplier worldwide [10].

\section{Materials and Methods}

The materials used in the study were:

Raw mechanically powdered gum $(55 \mathrm{~kg})$;

Spray dried gum (50 g);

Purified water;

Fluid bed drier machine Indian made;

Agar culture media.

\section{Methodology}

The raw gum was transformed into mechanically ground form; 50 $\mathrm{kg}$ of the grinded gum was treated in the fluid bed drier machine to obtain granulated form. A protocol for performing the procedure of granulation was designed and followed in monitoring the process of granulation. The machine was programmed to have a temperature range of $7^{\circ} \mathrm{C}$ inlet and $400^{\circ} \mathrm{C}$ outlets while spraying of $300 \mathrm{~mL}$ of water per minute. The process was repeated in a frequency of five times every 10 min (Figure 1).

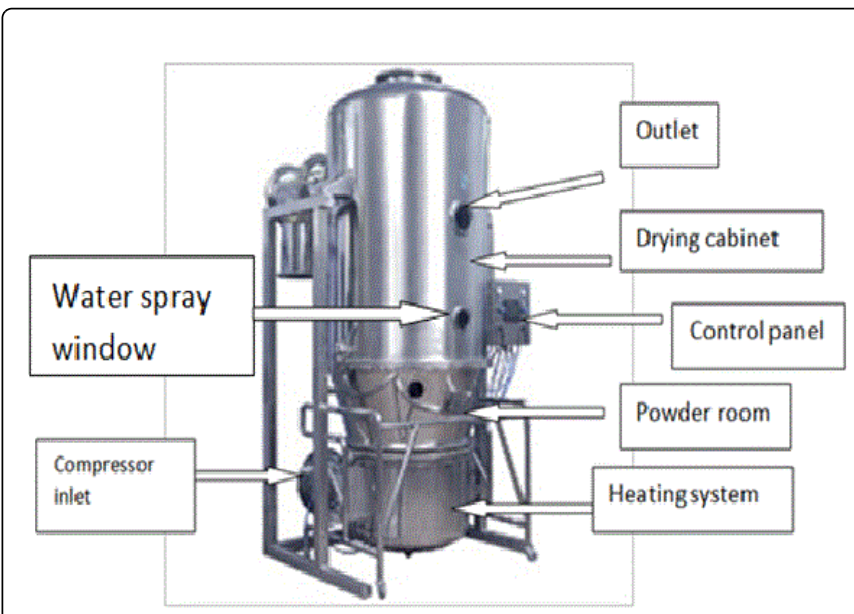

Figure 1: Fluid bed drier.

The granulated gum was then collected and studied in comparison with the mechanical grund and equal weight of spray dried form through the following steps:

$5 \mathrm{~g}$ of each of the three forms were let to dissolve in $100 \mathrm{~mL}$ of distilled water. Nine samples of each form were prepared.

$10 \mathrm{~mL}$ from each of the three forms were taken while continuously steering and placed into a pre-weighed dry container.

The sampling was repeated in intervals of $1,2,5,10,20,30,40,50$, and 60 min consecutively.
The samples were then subjected to evaporation and reweight.

A plot of solute weights in grams against time intervals was constructed for each form (Tables 1-3).

\begin{tabular}{|l|l|}
\hline Batch size & $\mathbf{5 0} \mathbf{~ k g}$ \\
\hline \multicolumn{2}{|l|}{ Grinding of gum into mechanical powder } \\
\hline Water treatment process was done \\
\hline Water analysis test was done (BP complying result) \\
\hline Water quanity for granulation & $20 \mathrm{~L}$ \\
\hline In Let Temp & $70^{\circ} \mathrm{C}$ \\
\hline Out Let Temp & $40^{\circ} \mathrm{C}$ \\
\hline Spray rate & $10 / \mathrm{min}(3000 \mathrm{~mL})$ \\
\hline Started at & $8: 30 \mathrm{Am}$ \\
\hline Ended at & $9: 30 \mathrm{Am}$ \\
\hline Resizing & Mesh size 40 \\
\hline Microbial test for finished product was done (BP. Complying) \\
\hline $\begin{array}{l}\text { Using automated fluid bed machine (as } \\
\text { Shown in the photo) }\end{array}$ \\
\hline
\end{tabular}

Table 1: Batch record, instant soluble gum.

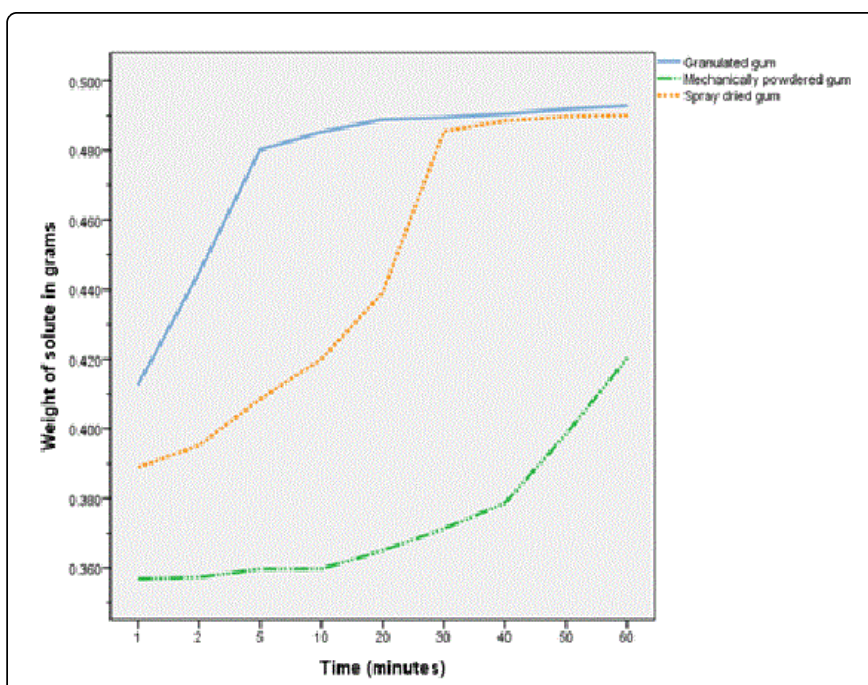

Figure 2: Quantity of dried solute versus time of dissolution.

\section{Results}

The results of this study are presented in tables and graphs (Tables 2 and 3).

\section{Discussion}

Efficiency of drugs depends on the quickness of solubility. The optimum acceptable disintegration limit is up to $15 \mathrm{~min}$ in case of core tablet and $30 \mathrm{~min}$ in case of the coated one and capsules referred to 
Page 3 of 4

international British pharmacopeia. Enhancement of gum arabic solubility is essential since gum arabic is becoming popular in industrial pharmacy. The process above helps to improve the solubility of gum acacia which add values to raw material without adding any other processor. Moreover the granulation process did not alter the general properties of the gum. Results of the current study proved a significant enhancement in solubility by granulation technique. It displayed statistically significant large amount of precipitate of solute after evaporation ( $\mathrm{p}$ value 0.05 ) (Table 1 ).

\begin{tabular}{|l|l|l|l|}
\hline Gum form & Mean weight in g & SD & P value \\
\hline $\begin{array}{l}\text { Granulated gum (instant soluble } \\
\text { form) }\end{array}$ & 0.4752 & 0.028 & \\
\cline { 1 - 4 } Spray dried gum & 0.4451 & 0.0436 & 0.05 \\
\cline { 1 - 3 } Mechanically powdered & 0.3741 & 0.0219 & \\
\hline
\end{tabular}

Table 2: Weight in grams of dried solute of three gum forms after evaporation.

\begin{tabular}{|c|c|c|}
\hline Test & Specifications & Results \\
\hline \multirow{2}{*}{$\begin{array}{l}\text { Total viable } \\
\text { aerobic count }\end{array}$} & Bacteria not more than $102 \mathrm{CFU}$ & \multirow{2}{*}{ I c/g absent } \\
\hline & Fungi not more than $103 \mathrm{CFU}$ & \\
\hline $\begin{array}{l}\text { Detection of } \\
\text { Bacteria }\end{array}$ & $\begin{array}{l}\text { Red gram negative colonies in violet red } \\
\text { agar }\end{array}$ & No growth \\
\hline \multirow{2}{*}{ Escherichia coli } & $\begin{array}{l}\text { Red non-mucoid colonies of gram } \\
\text { negative rods in Macconkey agar }\end{array}$ & No growth \\
\hline & Indole production & Negative \\
\hline \multirow{4}{*}{ Salmonella typhi } & $\begin{array}{l}\text { Well-developed of colorless colonies in } \\
\text { deoxychocolate agar }\end{array}$ & No growth \\
\hline & $\begin{array}{l}\text { Developed of red colonies with or without } \\
\text { black centers on XLD agar }\end{array}$ & No growth \\
\hline & $\begin{array}{l}\text { Small transparent colorless or pink or } \\
\text { opaque white colonies often surrounded } \\
\text { by a pink or red zone brilliant green agar }\end{array}$ & No growth \\
\hline & $\begin{array}{c}\text { Deep growth and forming gas on triple } \\
\text { sugar iron agar }\end{array}$ & No growth \\
\hline $\begin{array}{l}\text { Pseudomonas } \\
\text { aeruginosa }\end{array}$ & $\begin{array}{c}\text { Growth of gram negative rods colonies on } \\
\text { cetrmid agar }\end{array}$ & No growth \\
\hline \multirow{3}{*}{$\begin{array}{l}\text { Staphylococcus } \\
\text { aureus }\end{array}$} & $\begin{array}{l}\text { Black colonies of gram positive cocci } \\
\text { surrounded by clear zone on baird parker } \\
\text { agar }\end{array}$ & No growth \\
\hline & Coagulase positive & Negative \\
\hline & $\begin{array}{l}\text { Colonies surrounded with clear zone with } \\
\text { deoxyribonucleic acid agar }\end{array}$ & No growth \\
\hline
\end{tabular}

Table 3: Microbial contamination test of purified gum acacia.

Moreover a significant enhancement in the rate of solubility had been achieved as evident in graph proving that the granulation stage effectively enhance solubility and hence the superiority of granulated form to be used in pharmaceutical technology. This injects in the vein of solidifying the role of granulation process as being a well-known station in the solid dosage formulations, that it helps both flow ability and disintegration character since the flow ability is essential for direct compression material used as a binder in solid dosage form production [11].

As seen in the chart it was clear that the granulated form dissolves more easily and reaches a statistically significant large amount compared to the other two forms simultaneously. Upon referral to the international pharmacopeias the reported that the maximum accepted time for disintegration of tablets is $15 \mathrm{~min}$. The granulated form spent less than $5 \mathrm{~min}$ compared to the other forms which were $20 \mathrm{~min}$ to $2 \mathrm{~h}$. Therefore the granulated form is highly effective to be used in tablet formulation as binder, in suspension as a suspending agent, as coating agent, in eye drops formulation (Natural Tears), in addition to its utility as dietary supplement in tablet form. As far as the microbial test is concerned, it is evident in Table 2 above that the results are similar to the international standards in having no growth of Escherichia coli and Salmonella in the various culture media (Figures 2-4).

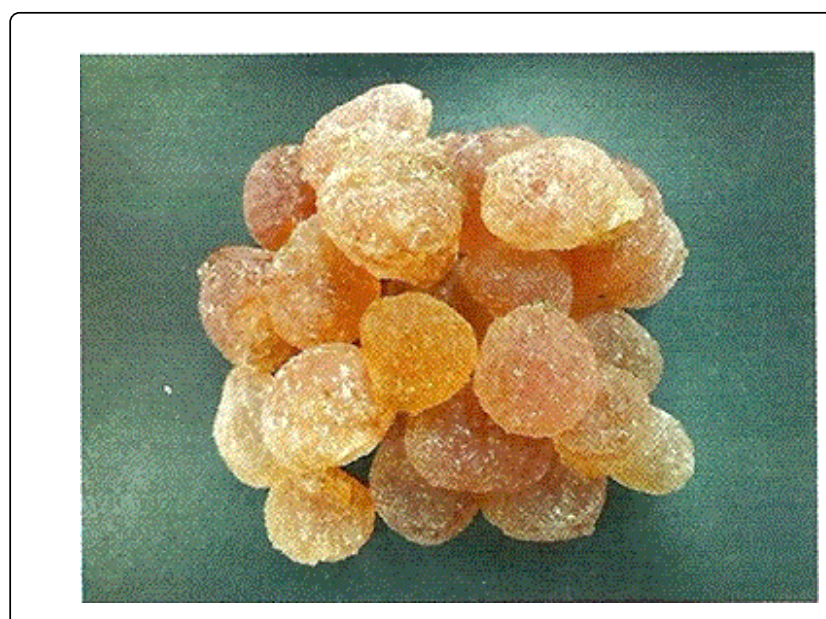

Figure 3: Hands pick raw gum.

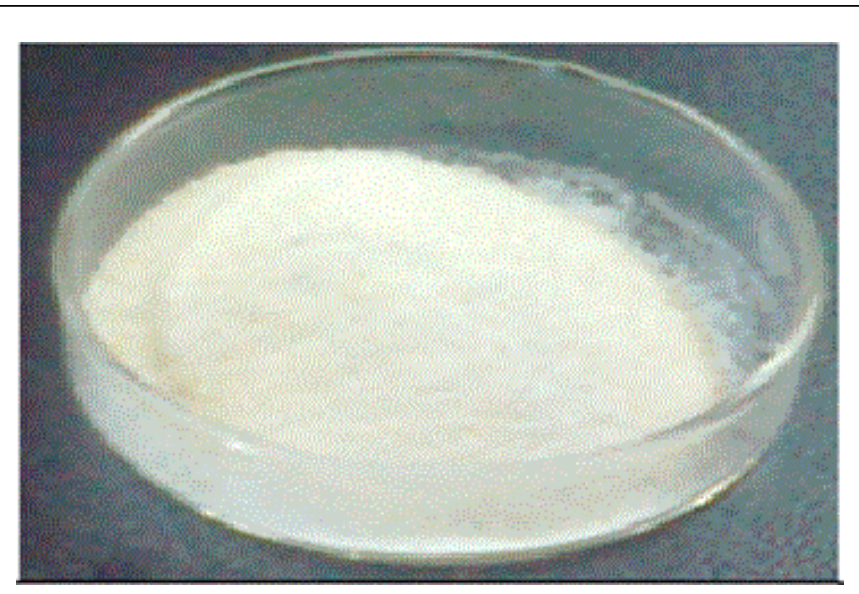

Figure 4a: Different three forms of gum: mechanical ground powder. 


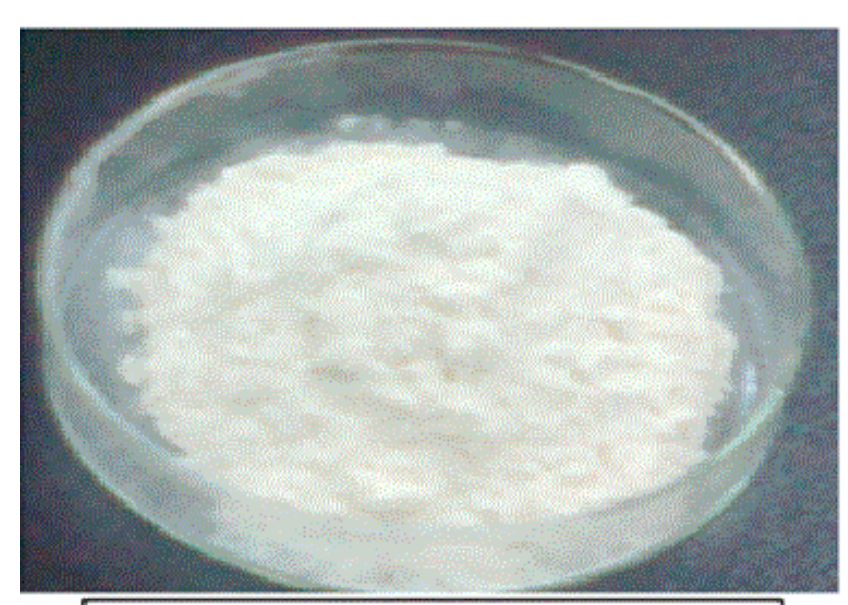

Figure 4b: Different three forms of gum: Spray dried powder.

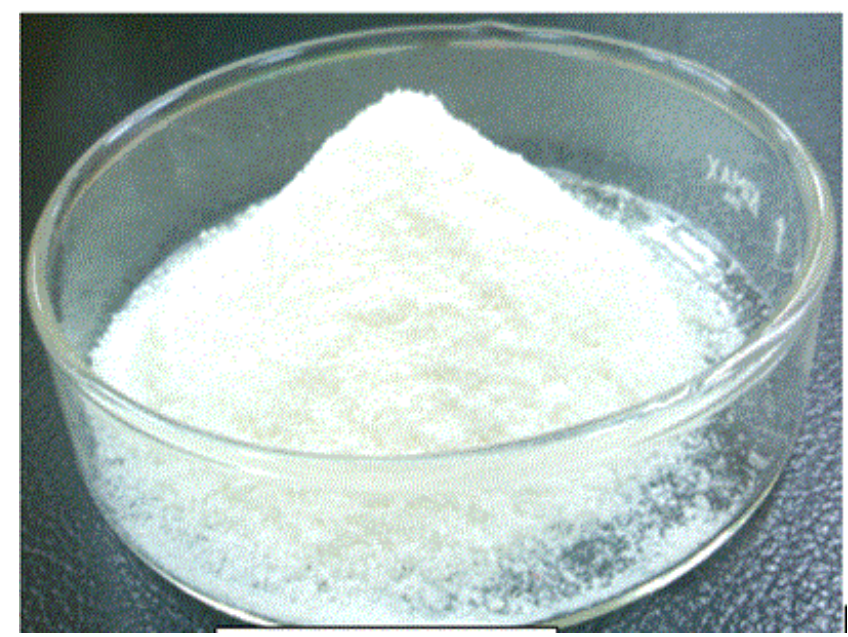

Figure 4c: Different three forms of gum: Instant soluble granules.

\section{Conclusion}

Granulation of gum arabic in fluid bed drier machine produces a form of gum which is instantly soluble. It dissolves easily moreover it is free of microbial growth (Figures $4 a-4 c$ ).

\section{Acknowledgment}

The works is gratified to the gum Arabic board for the generous funding and support. Our gratitude's to Karary University for their sponsoring the publications.

\section{References}

1. (2007) US Pharmacopeia, 30 NF 25 arabswell, p: 1051.

2. (2011) British Pharmacopoeia, Stationary office. London 1 Nine Elms. Lane, pp: $30-41$.

3. Wyasu, Okereke NZJ (2012) Improving the film forming ability of gum arabic. J Natl Prod Plant Resour 2: 314-317.

4. ElAmin EE, Blal ME, Mahmoud AE (2013) Gum Arabic (Acacia senegal (L.) Willd) Viscosity in Relation to Rainfall and Soil Metal Ions. Journal of Forest Products 2: 34 .

5. Rowe RC, Sheskey PJ, Quinn ME (2009) Handbook of Pharmaceutical Excipients (6th edn.). RPS publishing, Italy.

6. Attama AA, Adikwu MU, Okoli ND (2003) Studies on bioadhesive granules I: granules formulated with Prosopis africana (prosopis) gum. Chem Pharm Bull (Tokyo) 48: 734-737.

7. Achi A, Greenwood R, Akin-Isijola A (2000) Experimenting with a new emulsifying agent (tahini) in mineral oil. Int J Pharm Compound 4: 315-317.

8. Streubel A, Siepmann J, Bodmeier R (2003) Floating matrix tablets based on low density foam powder: effects of formulation and processing parameters on drug release. Eur J Pharm Sci 18: 37-45.

9. Smolinske SC (1992) Handbook of Food, Drug, and Cosmetic Excipients. Boca Raton, FL: CRC Press, pp: 7-11.

10. Sander SP, Friedl RR, Golden DM, Kurylo MJ, Moortgat GK, et al (2006) Chemical Kinetics and Photochemical Data for Use in Atmospheric Studies, Evaluation Number 16: Update of Key Reactions, JPL Publication, Jet Propulsion Laboratory, Pasadena, CA.

11. Lachman L, Lieberman HA, Kanic JL (1987) the theory and practice of industrial pharmacy (3rd edn.). Varghese publication house p: 319 . 